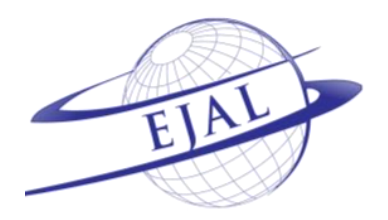

Available online at www.ejal.eu

\title{
Motivational Orientations of Secondary School EFL Learners toward Language Learning
}

\author{
Ramazan Yetkin ${ }^{a} *$ (D) , Semih Ekin ${ }^{a}+(\mathbb{D})$ \\ ${ }^{a}$ Hacettepe University, Ankara 06800, Turkey
}

\section{APA Citation:}

\begin{tabular}{l|l|l} 
Received 11 June 2018 & Received in revised form 15 July 2018 & Accepted 06 August 2018
\end{tabular}

Yetkin, R. \& Ekin, S. (2018). Motivational orientations of secondary school EFL learners toward language learning. Eurasian Journal of Applied Linguistics, 4(2), 375-388. doi: 10.32601/ejal.464202

\begin{abstract}
This study aimed to examine to what extent Turkish EFL learners' L2 motivational dispositions which are ideal L2 self, ought-to L2 self and language learning experiences predict their intended effort for language learning. The study was designed from a quantitative perspective in which the participants were given a composite instrument. The study was conducted at a state run secondary school in Turkey and the participants were 254 students including $5^{\text {th }}, 6^{\text {th }}, 7^{\text {th }}$ and $8^{\text {th }}$ graders. The results indicated that secondary level Turkish EFL students have high scores on all of the L2 motivation variables. However, the statistical analyses suggested that the participants' level of ought-to L2 self was significantly higher than their level of ideal L2 self. It was also seen that when the participants got older, their levels of ought-to L2 self appeared to indicate a decreasing trend. Besides, the results asserted that the secondary school students' intended effort for learning a language was found to be predicted mostly by language learning experiences, then ought-to L2 self and lastly ideal L2 self, according to hierarchical multiple regression analysis. The results were discussed in line with L2 motivational self system studies in the literature and it was concluded that the results in favor of ought-to L2 self might imply the existence of peer or community pressure in language learning process of secondary school EFL students in Turkish context.
\end{abstract}

(C) 2018 EJAL \& the Authors. Published by Eurasian Journal of Applied Linguistics (EJAL). This is an open-access article distributed under the terms and conditions of the Creative Commons Attribution license (CC BY-NC-ND) (http://creativecommons.org/licenses/bync-nd/4.0/).

Keywords: L2 motivational self system; ideal L2 self; ought-to L2 self; language learning experience; intended effort

\section{Introduction}

The effect of affective factors on language learning is indisputable, and the importance of motivation among those affective factors has grown over the years due to overwhelming amount of research bridging motivation and language learning (e.g. Dörnyei, 1998; Gardner \& Lambert, 1972; Oxford \& Shearin, 1994; Wang, 2009). Therefore, understanding what motivates people to learn a language has been a major impetus for many researchers in applied linguistics. Much research has been done in this vein, and in a meta-analytic study, Boo, Dörnyei and Ryan (2015) shed new light

\footnotetext{
* Corresponding author.

E-mail address: ryetkinn@gmail.com

${ }^{\dagger}$ ekinsemih@gmail.com
} 
on the situation. They claimed that the publications related to language learning motivation has increased dramatically from 2005 to 2013. This proliferation was because "the environments in these studies are dynamic and accommodating, as opposed to one that is static and stagnant" (Boo et al., 2015, p. 155). Therefore, it can be stated that new contexts would elicit quite different results, because every context has its unique characteristics. There are many different definitions of motivation; however, a thorough one was suggested by Williams and Burden (1997, p. 120) as "a state of cognitive and emotional arousal which leads to a conscious decision to act and which gives rise to a period of sustained intellectual and/or physical effort in order to attain a previously set goals".

Motivation studies were especially overwhelmed by the work of Gardner and his friends in Canadian context where British and French people lived in the same territory which created a multilingual environment. Gardner and his contemporary associates tried to understand language learning motivation by examining the people's attitudes toward the target language community. Then, Gardner and Lambert (1972) came up with the idea of integrativeness, instrumental motivation and attitudes towards the learning situation (also Gardner, 1985). Integrativeness, according to Moskovsky, Assulaimani, Racheva and Harkins (2016, p. 642) was about "incorporating attitudes toward the target language group, interest in foreign languages and integrative orientation". Instrumental motivation was about being motivated to achieve some practical goals. Lastly, attitudes toward the learning situation was more related with teacher, coursebook and process evaluation. The integrative motivation and instrumental motivation were conceptualized as different orientations; however, they were found to be quite related and integrated in some other studies (i.e. Noels, Pelletier, Clément \& Vallerand, 2000). The learners with an integrative orientation of motivation were expected to become more successful according to this framework. However, the idea of integrativeness has been criticized by many researchers (Cootzey-Van Rooy, 2006; Lamb, 2004; Pavlenko, 2002; Warden \& Lin, 2000). People with globalized identities with pluralism, multiple ethnicities and cultures challenge the idea of integrating with the target language community (Ushioda, 2011). In line with the idea of World Englishes (Kachru, 1990; Seidlhofer, 2009), the questions rise from the vagueness of who the target language (English) community is. This can quite change in today's world as British, Americans or Australians. Even more, there are many English language learners who live in English as a Foreign Language (EFL) settings and they have little opportunity to speak in the target language resulting in a situation in which people may not need to develop a sense of integrativeness towards the target language community (McEown, Noels, \& Saumure, 2014). Kormos and Csizer (2008) proposed four main reasons why integrativeness have been critized: "inapplicability to educational contexts, failure to integrate the cognitive theories of learning motivation, illegibility at the current age of globalization, and, as a result, the inability to capture the complexity of social identity" (p. 468). Therefore, new turns to understand how exactly language learning motivation can be conceptualized were taken by some other researchers. Especially 
from a cognitive view, the self-determination theory (Deci \& Ryan, 1985) in which they distinguished intrinsic motivation and extrinsic motivation gained much attention. Intrinsic motivation was being motivated to do an activity because of the enjoyment and enthusiasm in it while extrinsic motivation was performing an activity to achieve practical goals (Dörnyei, 1994; Noels et al., 2000; Williams \& Burden, 1997). There were also some other conceptualizations of the motivation which were Dörnyei and Otto's (1998) process model, Williams and Burden's (1997) socialconstructivist view, Ushioda's (2009) person-in-context relational view. Another conceptualization of motivation was made according to how people see themselves in the future in terms of language learning and what they do to achieve their goal oriented L2 identity resulted from a synthesis of self-discrepancy theory (Higgins, 1987) and possible selves theory (Markus \& Nurius, 1986); and this one was proposed by Dörnyei $(2005,2009)$ as L2 motivational self system (L2MSS). L2MSS also encompassed the integrativeness (Pawlak, 2012). According to self-discrepancy theory, there are three domains of the self which are actual self (the current self), ideal self (beliefs about what a person would ideally like to be) and ought self (beliefs about what a person should be). The important point here is if there is a huge discrepancy between actual self and ideal or ought self, the person can have motivational problems; however, if the discrepancy is moderate or lower, the person will be motivated to close the discrepancy (Strauman \& Higgins, 1988). The other theory which L2MSS was based on was possible selves theory (Markus \& Nurius, 1986). According to possible selves theory, there are different possible selves of people which can be ideal, ought, feared self etc. If people have positive possible selves, their motivation will be affected positively and if they have negative ones, their motivation will accordingly be affected negatively (Dörnyei \& Ryan, 2015). In consonance with these ideas, L2MSS has three different aspects:

Ideal L2 self concerns a person who has an enthusiastic and ideally shaped selfimage that s/he can become a speaker of an L2 well and competently (Dörnyei, 2009). "It represents an ideal image of the kind of L2 user one aspires to be in the future" (Papi, 2010, p. 468). Ideal L2 self also includes the integrative orientation of motivation because it has a connection with learning and communicating in an L2 efficiently by which the users can imagine themselves in the L2 community (Dörnyei \& Ushioda, 2009). If the learners can see a difference between their Ideal L2 self and actual self, they will be motivated to bridge this discrepancy to reach their ideal goals in terms of learning a language (Lamb, 2012).

Ought-to L2 self is related to the "the attributes that one believes one ought to possess to meet expectations and to avoid possible negative outcomes" (Dörnyei, 2009, p. 29). It can be regarded as an extrinsic part of the proposed L2 motivation framework. The ought-to L2 self can be an output of the situation in which the learners are afraid of losing a profession or failing in an exam, and it can also develop when the learner seeks for societal approval by meeting expectations of family, friends, teachers and the other people around them (Kim, 2012). For all these reasons, 
it can also be described as "a less-internalised type of instrumental disposition" (Kim, 2009, p. 276).

L2 learning experience is conceptualized as "situated, 'executive' motives related to the immediate learning environment and experience (e.g., the impact of the teacher, the curriculum, the peer group, the experience of success)" (Dörnyei, 2009, p. 29). Both ideal and ought-to L2 selves are related to future-based self-images; L2 learning experience, in contrast, is about what is happening right now and is related to the attitudes of the learners to the current learning context. L2 learning experience basically investigates interactions and relationships between internal (students themselves) and external factors embedded in the learning process (Liu \& Thompson, 2018).

L2MSS has been studied in different contexts and settings to understand what motivational dispositions of the language learners are. According to the results, ideal L2 self was found to be an important predictor of intended learning effort and motivation (Taguchi, Magid, \& Papi, 2009; Kim, 2012; Kim \& Kim, 2012; Ueki \& Takeuchi, 2013). Much research was done in L2MSS framework in the world; however, there seem very few studies on motivation and L2MSS when reviewing the literature in Turkey. According to these limited number of studies which was done on integrative or instrumental motivation, Turkish students were found to have moderate to high level of motivation towards language learning (e.g. Kizlltepe, 2000; Öztürk \& Gürbüz, 2013; Özgür \& Griffiths, 2013). The studies based on L2MSS in Turkish context are also very limited and they were investigated by some other variables like willingness to communicate or perceptual learning styles etc. (e.g. Demir-Ayaz \& Erten, 2017; Öz, 2016; Öz, Demirezen \& Pourfeiz, 2014; KanatMutluoglu, 2016). Besides, when reviewing the literature, most of the studies on L2MSS included high school and university students in Turkish context and other contexts (Far, Rajab \& Etemadzadeh, 2012; Göktepe, 2014; Kormos \& Csizér, 2008; Liu \& Thompson, 2018; Moskovsky et al., 2016; Papi, 2010; You \& Dörnyei, 2016). It seems that the situation for primary or secondary school students (aged between 1013) who can be called as young adolescents remains unclear.

L2 motivational self system is a recent construct dealing with predispositions toward language learning. Similarly, intended effort looks for predispositions that learners put effort toward their future language learning process. There seems a gap in the literature in terms of two important points: firstly, there is not a purely L2MSS-based study which directly examines the relationships among the Ideal L2 self, Ought-to L2 self and Language learning experience in relation to the criterion measure "intended efforts" of the learners in Turkey. Secondly, most of the L2MSS studies used high school and university students as participants and they did not include primary or secondary level students whose emotion and affection levels are quite different than their elder ones. In that regard, the current study was conducted to bridge these gaps by revealing the effect of L2MSS on primary level students' intended efforts. For this reason, following research questions were answered; 
1. What are the secondary school EFL learners' L2MSS and intended effort levels?

2. Is there any difference between participants' ideal L2 self and ought to L2 self?

3. What are the main and interaction effects of gender and grade on L2 motivation and intended effort?

4. When the effect of gender is kept constant, is the L2 motivation self system (ideal L2 self, ought to L2 self, language learning experience) able to predict significant amount of variance in intended effort?

\section{Method}

\subsection{Setting and participants}

The data was collected from a state run secondary school in Turkey. 254 secondary school foreign language learners participated in the study. 124 of the participants were males and 129 of them were females. Their ages were ranging from 9 to 15, and the most frequently occurring age was 13 . The participants were selected through purposeful sampling to make sure that all the learners are from secondary school and they are studying English as a foreign language. All four secondary graders $(5,6,7,8)$ were represented in the study.

\subsection{Instrumentation}

The main instrument used in this study was a composite questionnaire compiled and developed by You, Dörnyei and Csizér (2016) to measure motivation and vision. In the current study, a Turkish version of the study translated by Doğan (2017) was used. The questionnaire was a 73-item 6 point Likert scale ranging from strongly disagree to strongly agree. The higher value for each variable endorses the higher agreement level for that very variable. Even though the instrument was a composite one with 73 items, not all the items and components were utilized in the current study. L2 motivational self system including ideal L2 self, ought to L2 self and language learning experience, and intended effort components were employed in this study. Participants' demographic information were gathered through a second questionnaire attached to the main questionnaire.

\subsection{Data collection}

The data were collected in 2018 spring semester from a secondary school. After getting the necessary permission from the school directorate, all the English teachers were informed about the study and its procedures. Then, the researcher visited all the classrooms one by one just before each class hour happens to start. After giving a short information about the research and its confidentially, the researcher distributed the questionnaires to the voluntaries. It took around 15 minutes for the participants to complete the questionnaires. There were 3 sections in each grade that is equal to 12 different sections. The data collection took two days in total. 


\subsection{Data analysis procedure}

The obtained data were entered to Statistical Package for the Social Sciences (SPSS 25) software at first. Then, the data was subjected to test of normality to check whether the data are normally distributed, for the non-normal distribution asks for very different means of analysis. After a rigorous investigation of the statistical outcomes by looking at mean, trimmed-mean values, Kolmogorov-Smirnov results, skewness and kurtosis results as well as plots such as histogram and q-q plots, it was understood that the data were normally (parametrically) distributed. The reliability of the scale was computed as .93.

Secondly, descriptive results were employed for each component to see participants (dis) agreement level toward L2MSS and intended effort variables. In order to see the difference between ideal L2 self and ought to L2 self, a paired-samples t-test was computed. The difference in each component resulting from participants' gender and grades were calculated through two way between-groups multivariate test of variance (MANOVA). Lastly, in order to see whether motivational self systems predict and explain participants' intended efforts after controlling for gender, a hierarchical multiple regression was run. Before running MANOVA and regression analyses, all the accompanying assumptions; normality, linearity, univariate and multivariate outliers, homogeneity of variance-covariance matrices, and multicollinearity were checked and no serious violations were noted. At the end, a principal component analysis was run to check the used questionnaire's construct validity.

\section{Results}

The current study aims to reveal secondary school EFL learners' L2 motivational selves and intended effort. In this regard, first research question "What are the secondary school EFL learner's L2MSS and intended effort levels" intends to reveal descriptive results for all four variables as presented below in the Table 1.

Table 1. Descriptive results

\begin{tabular}{llll}
\hline & $N$ & $M$ & $S D$ \\
\hline Intended effort & 253 & 4.658 & 1.199 \\
Lang. L. Experience & 253 & 4.558 & 1.116 \\
Ought to L2 self & 253 & 4.465 & 1.110 \\
Ideal L2 self & 253 & 4.286 & 1.372 \\
\hline
\end{tabular}

As indicated in the table, intended effort held the highest mean value among all the variables $(M=4.65, S D=1.19)$, which indicated that participants agree that their intended effort is by far the most important factor for their language learning. Intended effort was followed by language learning experience $((M=4.55, S D=1.11)$. Language learning experience held the highest agreement level among all three 
motivational self-systems components followed by ought to L2 self ( $M=4.46, S D=$ 1.11), and ideal L2 self $(M=4.28, S D=1.37)$.

Table 2. L2 motivational selves: ideal L2 self, ought to L2 self

\begin{tabular}{lllllll}
\hline Motivation & $N$ & $M$ & $S D$ & $d f$ & $t$ & $p$ \\
\hline Ideal L2 self & 253 & 4.286 & 1.372 & & & \\
Ought to L2 self & 253 & 4.465 & 1.110 & 252 & -2.739 & .007 \\
\hline
\end{tabular}

The aim of the second question "Is there any difference between participants' ideal L2 self and ought to L2 self" was to reveal EFL learners' dispositions toward different motivators. For this reason, A paired-samples t- test was conducted to reveal secondary school EFL learners' ideal L2 self and ought to L2 self-motivation levels. There was a statistically significant difference between ideal L2 self ( $M=4.28, S D=$ 1.37) and ought to L2 self $(M=4.46, S D=1.01), t(252)=-2.73, p=.007$ (two-tailed) of participants in which the latter held a higher score.

The aim of the third question "What are the main and interaction effects of gender and grade on L2 motivation and intended effort" was to explore whether participants' motivation and intended effort are stable across different grade and gender groups. For that reason, a two-way between groups multivariate analysis of variance was performed. Preliminary assumptions were checked for normality, linearity, univariate and multivariate outliers, homogeneity of variance-covariance matrices, and multicollinearity, with no serious violations noted.

Grade seems to exercise main effects on motivation and intended effort provided by language learners for their future language learning, (Wilks' Lambda $=.816, F=$ 4.190, $\mathrm{p}<000$ ), also with a small effect size (partial eta square=.06). A breakdown of total scores according to the grade is given in Table 3 .

Table 3. Descriptive results of grades for motivation and intended effort

\begin{tabular}{|c|c|c|c|c|c|c|c|c|c|c|c|c|}
\hline & & 5 & & & 6 & & & 7 & & & 8 & \\
\hline & $N$ & $M$ & $S D$ & $N$ & $M$ & $S D$ & $N$ & $M$ & $S D$ & $N$ & $M$ & $S D$ \\
\hline Ideal & 83 & 4.89 & 1.12 & 57 & 3.96 & 1.28 & 49 & 4.07 & 1.35 & 60 & 3.99 & 1.48 \\
\hline Ought & 83 & 5.01 & 1.35 & 57 & 4.31 & 1.02 & 49 & 4.44 & 1.11 & 60 & 3.91 & 1.19 \\
\hline L.exp & 83 & 4.91 & .96 & 57 & 4.57 & .77 & 49 & 4.31 & 1.22 & 60 & 4.28 & 1.34 \\
\hline Effort & 83 & 5.09 & 1.03 & 57 & 4.61 & .94 & 49 & 4.43 & 1.30 & 60 & 4.28 & 1.37 \\
\hline
\end{tabular}

Descriptive statistics indicated that significant grade differences were in favor of 5 grade students and there was a sharp decrease over the years of education. After the Bonferroni adjusted alpha level of .17 , intended effort ( $5=M=5.09 ; 6=M=4.61 ; 7=M=$ $4.43 ; 8=M=4.28 ; F=4.79 ; p=.003$; partial eta squared=.05), ought to L2 self ( $5=M=$ $5.01 ; 6=M=4.31 ; 7=M=4.44 ; 8=M=3.91 ; F=12.27 ; p=.000 ;$ partial eta squared=.13), language learning experience $(5=M=4.91 ; 6=M=4.57 ; 7=M=4.31 ; 8=M=4.28 ; F=3.87$; 
$p=.010 ;$ partial eta squared $=.04)$, and ideal L2 self $(5=M=4.89 ; 6=M=3.96 ; 7=M=4.07$; $8=M=3.99 ; F=7.07 ; p=.000$; partial eta squared=.08) were the variables reached at statistical significance in which 5 grade language learners always held the highest mean values.

Gender, too seems to exert main effects on motivation and intended effort given by language learners for their future language learning (Wilks' Lambda=.907, $F=6.131$, $p<000$ ), also with a medium effect size (partial eta square=.09). A breakdown for each test score according to gender can be seen in Table 4 .

Table 4. Descriptive results of gender for motivation and intended effort

\begin{tabular}{lllllll}
\hline & & Female & & \multicolumn{2}{l}{ Male } \\
& $N$ & $M$ & $S D$ & $N$ & $M$ & $S D$ \\
\hline IdealL2self & 128 & 4.69 & 1.16 & 121 & 3.88 & 1.42 \\
OughttoL2self & 128 & 4.73 & .96 & 121 & 4.20 & 1.17 \\
Lang. L. Exp. & 128 & 4.85 & .89 & 121 & 4.25 & 1.22 \\
Intended E. & 128 & 5.00 & .93 & 121 & 4.29 & 1.33 \\
\hline
\end{tabular}

Descriptive statistics indicated that significant gender differences were in favor of female students. After the application of Bonferroni adjusted alpha value of .17, it appeared that participants incline to be effected by the following variables in mean order for their future language learning; intended efforts (female $=M=5.00$; male $=M=4.29 ; F=18.04 ; p=.000 ;$ partial eta squared=.07); language learning experience (female $=M=4.85 ;$ male $=M=4.25 ; F=16.73 ; p=.000 ;$ partial eta squared=.06); ought to L2 self (female $=M=4.73 ;$ male $=M=4.20 ; F=11.05 ; p=.001$; partial eta squared=.04); and ideal L2 self (female $=M=4.69 ;$ male $=M=3.88 ; F=19.52 ; \quad p=.000 ;$ partial eta squared=.07).

A two-way MANOVA analysis revealed no significant interaction effect between grade and gender on participants' motivation and intended efforts (Wilks' Lambda=.949, $F=1.049, p>05$.).

Table 5. Hierarchical multiple regression

\begin{tabular}{|c|c|c|c|c|c|c|}
\hline \multirow[t]{2}{*}{ Predictors } & \multirow[t]{2}{*}{$\beta$} & \multirow[t]{2}{*}{$t$} & \multirow[t]{2}{*}{ Sig. } & \multicolumn{3}{|c|}{ Correlations } \\
\hline & & & & Zero order & Partial & Part \\
\hline Gender & .295 & 4.851 & .000 & .295 & .295 & .295 \\
\hline Ideal L2 self & .262 & 4.879 & .000 & .678 & .298 & .185 \\
\hline Ought to L2 self & .281 & 4.905 & .000 & .708 & .300 & .186 \\
\hline Lang. L. Experience & .362 & 6.796 & .000 & .717 & .399 & .258 \\
\hline
\end{tabular}

Note: $R^{2}$ change for model $1=.087$; for model $2=.561$.

Hierarchical multiple regression was used to assess the ability of motivation factors to predict participants' intended effort after controlling for the influence of gender. Preliminary analyses were conducted to ensure no violation of the assumptions of normality, linearity, multicollinearity and homoscedasticity. Gender was entered at step 1, explaining almost 9\% of the variance in intended effort. After entry of the L2 
motivational self-system factors at Step 2 the total variance explained by the model as a whole was $64.2 \%, F(4,244)=112.37, p<.000$. The motivation factors explained an additional $56.1 \%$ of the variance in intended effort, after controlling for gender, $\mathrm{R}$ squared change $=.561, F$ change $(3,244)=129.72, p<.000$. In the final model, all three of the control measures were statistically significant, ranked according to their beta $(\beta)$ values; language learning experience $(\beta=.36, p<.05)$; ought to L2 self $(\beta=$ $.28, p<.05)$; ideal L2 self $(\beta=.26, p<.05)$.

\section{Discussion}

The present study tried to investigate and reveal secondary school EFL learners' predispositions toward their language learning motivation in the future. In the study context, English is mostly started to be taught just in the very beginning of primary school in the state run education institutions. In that regard, current study emphasizes the importance of EFL learners' predispositions about their long-run language learning motivations. The first question indicated that EFL learners showed significant agreement level for all the effort and motivation variables which are ideal L2 self, ought-to L2 self and language learning experience. However, they mostly agreed that their intended effort was by far the most important factor among all the variables which indicated that participants saw their effort very valuable and they tried hard. Similarly, motivational factors also got very high agreement level and EFL learners agreed that their language motivators were also crucial alongside their effort. Ideal L2 self levels were found to be changing from moderate to high which is in line with the results of some studies in Turkish context (i.e. Demir-Ayaz \& Erten, 2017; Göktepe, 2014). Ought-to L2 self levels of the students were also found to be high which may suggest that Turkish students can be affected by societal expectations in terms of L2 learning (Göktepe, 2014). It also seems that the students are quite satisfied with their language learning experience which encompasses the immediate environment, the teachers, the teaching program etc. according to Dörnyei (2009). The analysis of EFL learners' motivational selves revealed that their ideal L2 self levels dominated and were significantly different from their ought-to L2 self levels which may suggest that their inner related motivation levels were suppressed by their outerrelated motivational dispositions. Although descriptive results indicated that both ideal and ought to L2 selves were quite important, EFL learners' first consideration appeared to be extrinsic factors. This could be explained by the study of setting and culture. Inclusively in the current setting, if not exclusively, the notion of so-called "community pressure or peer pressure" may play a key role throughout language learning process which is line with the previous research done in similar EFL contexts like Korea or Iran (Kim \& Kim, 2012; Taguchi et al., 2009), because according to Kim (2012, p. 33), Korean EFL learners are also "exposed to an excessive amount of social pressure to learn English as a means of securing what is considered to be a positive future". In that regard, EFL learners' predispositions toward language may be regarded as being deeply affected by such extrinsic sources. 
The impact of grade and gender was investigated through a two-way multivariate analysis of variance in order to obtain main and interaction effects over the variables. Even though no statistically significant interaction effect was noted, it appeared that both gender and grade exerted significant difference over L2 learners' motivational selves and efforts. Firstly, gender effect positively loaned on females who had higher pre-disposed values toward language learning. This result was verified many previous language learning studies where females mostly dominated males in terms of the effort (e.g. Lamb, 2012; Fan, Lindt, Arroyo-Giner, \& Wolters, 2009). In the current context, this difference might be explained through planning. Females always seemed to be more planned than males (e.g. Dayığlu \& Türüt-Aşık, 2007) Secondly, multivariate results indicated significant differences on $5^{\text {th }}$ graders' favor. When the descriptive results were analyzed, it appeared that there was a slow but steady decrease over the years. In the study context, L2 learning starts from $2^{\text {th }}$ grade on. Since L2 motivational selves and intended effort explained learners' predispositions toward language learning, this grade difference could be explained by learners' language experience. It seemed that learners' language learning experience differed from their dispositions, henceforth, their mean values inclined to decrease over the years when they were exposed to more language experience which is in contrast with the findings of Kim (2012) in Korean setting.

The scrutiny of intended effort, language learning experience, ideal L2 self and ought to L2 self indicated strong positive correlation with each other. After controlling for gender, regression analysis indicated that more than half of the variance in secondary school EFL learners' intended efforts came from their L2 motivational self which indicated that their motivational predispositions toward language learning was more than crucial for their language related efforts. When the L2 motivational selves were examined one by one in an order, according to their prediction power for intended effort, it was seen that students were likely to have an increasing level of ideal L2 self until the $8^{\text {th }}$ grade which was different than the findings of Sung (2014). While they had a high level of Ought-to L2 self in $4^{\text {th }}$ grade, it was seen that Ought-to L2 self was in a decreasing trend and was leveled with ideal L2 self until $8^{\text {th }}$ grade which indicated the importance of "others" in students' language learning motivation. The intended effort was found to be predicted by language learning experience, ideal L2 self and ought-to L2 self. Language learning experience explained the greater variance over intended effort followed by ought to L2 self and ideal L2 self, in contrast to Lamb (2012) claiming that Ought-to L2 self "has not been found to explain much of the variance in the criterion measure of motivated learning behavior" (p. 1014). When the order of the motivational impacts was analyzed, it seemed to appear that the importance of family, friends and others, if not significant others, over L2 learners' efforts toward language learning was very much important.

\section{Conclusions}

The present study was carried out to reveal secondary school EFL learners' motivational dispositions and efforts toward language learning in the future. It was 
needed to research secondary school students' dispositions since very limited number of studies was designated to address secondary school level, though most of the studies were conducted to address university context. In the current study, it was revealed that learners' intended effort shaped how they see language learning process. It was clear that effort played the key role in learners' dispositions toward language learning. EFL learners' ought-to L2 self seemed to dominate their ideal L2 self when considering language learning. This could be explained through local culture in which peer or community pressure affected education. Since both motivational and effort variables indicated learners' dispositions toward language learning, $5^{\text {th }}$ grade students appeared to have the highest values for all variables. A steady decrease was observed over the years and $8^{\text {th }}$ graders presented the lowest values for each variable. It could be said that this steady decline could be due to the gap between the learners' L2 selves and actual language learning processes, and the more learners engaged in language learning process and proceed, the more their predispositions seemed to decline. Additionally, females dominated males over motivation and effort, which may have resulted from being more systematic and planned. Language learning experience seemed to be the best predictor of intended effort. It could be deduced that what learners saw around could affect and shapes their minds toward language learning.

Many implications could be drawn from the present study. At first, language teachers should try to bridge the gap between learners' self and actual dispositions toward language learning. Teachers should not only motivate their learners about the language learning and its importance, but also set realistic and achievable goals. Secondly, teachers should bring some role models to their classrooms so that the learners can experience some authentic success samples before them. Lastly, the teacher should bridge the gap between ideal and ought to L2 selves by taking some measures such as motivating students or talking to families. Both ideal and ought to L2 selves appeared to affect language learning, but both dispositions should not dominate each other for a healthier language learning process.

Even though current study disclosed valuable insights and implications to the literature, further studies are needed to address current study topic for more insightful and detailed results. Firstly, a mixed- method approach should be used to investigate learners' motivational dispositions and efforts toward language learning. Inclusion of qualitative data can bring many valuable comprehensions to the topic. Secondly, a comparison of secondary and tertiary level EFL learners can distinguish the difference between grade and gender difference over learners' dispositions. Lastly, an experimental study including motivation training interventions can be conducted to assess learners' dispositions toward language learning more genuinely.

\section{References}

Boo, Z., Dörnyei, Z., \& Ryan, S. (2015). L2 motivation research 2005-2014: Understanding a publication surge and a changing landscape. System, 55, 145-157. 
Cootzee-Van Rooy, S. (2006). Integrativeness: Untenable for world Englishes learners?. World Englishes, 25(3-4), 437-450.

Dayioğlu, M., \& Türüt-Aşik, S. (2007). Gender differences in academic performance in a large public university in Turkey. Higher Education, 53(2), 255-277.

Deci, E. L., \& Ryan, R. M. (1985). The general causality orientations scale: Self-determination in personality. Journal of Research in Personality, 19(2), 109-134.

Demir-Ayaz, A., \& Erten, İ.H. (2017). The relationship between EFL learners' future L2 selfguides, vision and language learning motivation. In Şehnaz Şahinkarakas and Jülide İnözü (Eds), The role of the self in language learning (pp. 7-24). Newcastle, UK: Cambridge Scholars Publishing.

Doğan, G. (2017). The effect of gender and 12 proficiency on learners' motivational dispositions and vision. International Journal of Language Academy, 5(3), 66-83.

Dörnyei, Z. (1994). Motivation and motivating in the foreign language classroom. The Modern Language Journal, 78(3), 273-284.

Dörnyei, Z. (1998). Motivation in second and foreign language learning. Language Teaching, 31(3), 117-135.

Dörnyei, Z. (2005). The psychology of the language learner: Individual differences in second language acquisition. Mahwah, NJ: Erlbaum.

Dörnyei, Z. (2009). The L2 motivational self system. Motivation, Language Identity and the L2 self, 36(3), 9-11.

Dörnyei, Z., \& Ottó, I. (1998). Motivation in action: A process model of L2 motivation. Working Papers in Applied Linguistics, 4, 43-69.

Dörnyei, Z., \& Ryan, S. (2015). The psychology of the language learner revisited. New York, NY: Routledge.

Dörnyei, Z., \& Ushioda, E. (Eds.). (2009). Motivation, language identity and the L2 self. UK: Multilingual Matters.

Far, H. R., Rajab, A. B., \& Etemadzadeh, A. (2012). Examining the relationship between L2 motivational self system and L2-learning among TESL students. US-China Foreign Language, 10(6), 1266-1270.

Fan, W., Lindt, S.F., Arroyo-Giner, C.A., \& Wolters, C.A. (2009). The role of social relationships in promoting student academic self-efficacy and MIMIC approaches to assess factorial mean invariance. International Journal of Applied Educational Studies, 5, 34-53.

Gardner, R.C. (1985). Social psychology and language learning: The role of attitudes and motivation. London, UK: Edward Arnold.

Gardner, R. C., \& Lambert, W. E. (1972). Attitudes and motivation in second language learning. Rowley, MA: Newbury House.

Goktepe, F. T. (2014). Attitudes and motivation of Turkish undergraduate EFL students towards learning English language. Studies in English Language Teaching, 2(3), 314.

Higgins, E. T. (1987). Self-discrepancy: A theory relating self and affect. Psychological Review, 94(3), 319-340.

Kachru, B. B. (1990). World Englishes and applied linguistics. World Englishes, 9(1), 3-20.

Kanat-Mutluoglu, A. (2016). The influence of ideal L2 self, academic self-concept, and intercultural communicative competence on willingness to communicate in a foreign language. Eurasian Journal of Applied Linguistics. 2(2), 27-46.

Kim, T.Y., (2009). The sociocultural interface between ideal self and ought-to self: A case study of two Korean students' ESL motivation. In Dornyei, Z., Ushioda, E. (Eds.), Motivation, language identity and the L2 self. Multilingual Matters, Clevedon, pp. 274-294. 
Kim, T. Y. (2012). The L2 motivational self system of Korean EFL students: Cross-grade survey analysis. English Teaching, 67(1), 29-56.

Kim, Y. K., \& Kim, T. Y. (2012). Korean secondary school students' L2 learning motivation: Comparing L2 motivational self system with socio-educational model. English Language \& Literature Teaching, 18(1), 115-132.

Kiziltepe, Z. (2000). Attitudes and motivation of Turkish EFL students towards second language learning. ITL-International Journal of Applied Linguistics, 129(1), 141-168.

Kormos, J., \& Csizér, K. (2008). Age-related differences in the motivation of learning English as a foreign language: Attitudes, selves, and motivated learning behavior. Language Learning, 58(2), 327-355.

Lamb, M. (2004). Integrative motivation in a globalizing world. System, 32(1), 3-19.

Lamb, M. (2012). A self system perspective on young adolescents' motivation to learn English in urban and rural settings. Language Learning, 62(4), 997-1023.

Liu, Y., \& Thompson, A. S. (2018). Language learning motivation in China: An exploration of the L2MSS and psychological reactance. System, 72, 37-48.

Markus, H., \& Nurius, P. (1986). Possible selves. American Psychologist, 41(9), 954-969.

McEown, M. S., Noels, K. A., \& Saumure, K. D. (2014). Students' self-determined and integrative orientations and teachers' motivational support in a Japanese as a foreign language context. System, 45, 227-241.

Moskovsky, C., Assulaimani, T., Racheva, S., \& Harkins, J. (2016). The L2 motivational self system and L2 achievement: A study of Saudi EFL learners. The Modern Language Journal, 100(3), 641-654.

Noels, K. A., Pelletier, L. G., Clément, R., \& Vallerand, R. J. (2000). Why are you learning a second language? Motivational orientations and self-determination theory. Language Learning, 50(1), 57-85.

Oxford, R., \& Shearin, J. (1994). Language learning motivation: Expanding the theoretical framework. The Modern Language Journal, 78(1), 12-28.

$\mathrm{O} z, \mathrm{H}$. (2016). Role of the ideal L2 self in predicting willingness to communicate of EFL students. In İ. H. Mirici, İ. H. Erten, H. Öz, \& I. Vodopija-Krstanovic (Eds.), Research papers as an Additional Language (pp. 163-182). Rijeka: Faculty of Humanities and Social Research.

Öz, H., Demirezen, M., \& Pourfeiz, J. (2014). Willingness to communicate of EFL learners in Turkish context. Learning and Individual Differences, 37, 269-275.

Özgür, B., \& Griffiths, C. (2013). Second language motivation. Procedia-Social and Behavioral Sciences, 70, 1109-1114.

Öztürk, G., \& Gürbüz, N. (2013). The impact of gender on foreign language speaking anxiety and motivation. Procedia-Social and Behavioral Sciences, 70, 654-665.

Papi, M. (2010). The L2 motivational self system, L2 anxiety, and motivated behavior: A structural equation modeling approach. System, 38(3), 467-479.

Pavlenko, A. (2002). Poststructuralist approaches to the study of social factors in second language learning and use. In V. Cook (Ed.), Portraits of the L2 user (pp. 277-302). Clevedon: Multilingual Matters.

Pawlak, M. (2012). The dynamic nature of motivation in language learning: A classroom perspective. Studies in Second Language Learning and Teaching, 2, 249-278.

Seidlhofer, B. (2009). Common ground and different realities: World Englishes and English as a lingua franca. World Englishes, 28(2), 236-245.

Strauman, T. J., \& Higgins, E. T. (1988). Self-discrepancies as predictors of vulnerability to distinct syndromes of chronic emotional distress. Journal of Personality, 56(4), 685-707. 
Sung, K. Y. (2014). L2 motivation in foreign language learning. Journal of Language and Linguistic Studies, 9(2), 19-30.

Taguchi, T., Magid, M., \& Papi, M. (2009). The L2 motivational self system amongst Chinese and Japanese learners of English: A comparative study. In Z. Dörnyei \& E. Ushioda (Eds.), Motivation, language identity and the L2 self (pp. 66-97). Bristol, UK: Multilingual Matters.

Ueki, M., \& Takeuchi, O. (2013). Forming a clearer image of the ideal L2 self: The L2 Motivational Self System and learner autonomy in a Japanese EFL context. Innovation in Language Learning and Teaching, 7(3), 238-252.

Ushioda, E. (2009). A person-in-context relational view of emergent motivation, self and identity. In Murray, G., Gao, A., Lamb, T. (Eds), Motivation, language identity and the L2 self, pp. 215-228.

Ushioda, E. (2011). Language learning motivation, self and identity: Current theoretical perspectives. Computer Assisted Language Learning, 24(3), 199-210.

Wang, B. (2009). Motivation and language learning. Asian Social Science, 5(1), 98.

Warden, C. A., \& Lin, H. J. (2000). Existence of integrative motivation in an Asian EFL setting. Foreign Language Annals, 33(5), 535-545.

Williams, M., \& Burden, R. L. (1997). Psychology for language teachers (Vol. 67). Cambridge, UK: Cambridge University Press.

You, C. J., \& Dörnyei, Z. (2016). Language learning motivation in China: Results of a largescale stratified survey. Applied Linguistics, 37(4), 495-519.

You, C. J., Dörnyei, Z., \& Csizér, K. (2016). Motivation, vision, and gender: A survey of learners of English in China. Language Learning, 66(1), 94-123.

\section{Copyrights}

Copyright for this article is retained by the author(s), with first publication rights granted to the Journal. This is an open-access article distributed under the terms and conditions of the Creative Commons Attribution license (CC BY-NC-ND) (http://creativecommons.org/licenses/by-nc-nd/4.0/). 